\title{
INDONESIAN CAPITAL MARKET REACTION ON THE REGULATION OF THE MINISTER OF FINANCE CONCERNING TECHNICAL INSTRUCTIONS ON INFORMATION ACCESS FOR INTEREST OF TAXATION
}

\author{
Diah Citraresmi S.A.A.S. ${ }^{*}$, Suardikha I.M.S. \\ Master's Program of Accounting, Faculty of Economics and Business, University of Udayana, \\ Bali, Indonesia \\ *E-mail: aasgdiahcitraresmi@gmail.com
}

\begin{abstract}
This study aims to determine whether there is a market reaction as a result of the announcement of Regulation of the Minister of Finance on Technical Guidelines on Access to Financial Information (PMK \#73/PMK.03/2017). Market reactions in this study were measured using abnormal return. The level of significance of the abnormal return was tested by One Sample t-test. The results of this study indicate a negative abnormal return. This study sugest that government should respond by appealing and inviting the community to follow the Voluntary Asset Disclosure with Final Rate Program (PAS Final Program).
\end{abstract}

\section{KEY WORDS}

Financial information, event study, abnormal return, market reaction, regulation, tax.

Financial institutions are businesses that rely on trust (Wijaya, 2016). This trust is closely related to banking secrecy. Bank secrecy is the most important thing because it concerns the security of customers' property. Therefore the Indonesian government guarantees it through provisions regulated by the banking and tax authorities. Regulation of Bank Indonesia number: 2/19 / PBI / 2000 stated that the banking should keep secret everything related to information about depositors and customer deposits (Kencana, 2017). related to taxation, the Law on General Provisions and Procedure of Taxation (UU KUP) regulates in Article 35 paragraph (2) that banking secrecy is eliminated by the written request of the Minister of Finance. Referring to the above, the tax authorities intend to obtain data or information concerning the customer's account for tax purposes or Taxpayer, it must start by the request for permission from the commissioner of the Financial Services Authority (OJK).

According to the Minister of Finance, now the Directorate General of Tax has data about the taxpayer who keeps the treasures abroad and within the country completely. But the data can not be followed up due to the limited ability of the Directorate General of Tax, and it is not apart from the existence of bank secrecy article in the Banking Act. So far, using the procedure manual of the process of verifying customer data or taxpayers takes a long time so that many tax inspectors get constraints in obtaining banking data information (Kencana, 2017). This is one of the reasons on May 8, 2017 President Joko Widodo issued Government Regulation in Lieu of Law (Perppu) No. 1 of 2017 on Access to Financial Information for Interest of Taxation. The Perppu is also issued to fulfill Indonesia's commitment to Automatic Exchange of Information (AEol) and must immediately establish legislation at the law level on access to financial information for tax purposes. A total of 101 countries have agreed to implement an automatic exchange of information (AEol) in the field of financial services for tax purposes. Currently as many as 100 countries or jurisdictions have committed to participate in AEol, with 50 countries starting in 2017, and 50 other countries by 2018, Indonesia following in 2018 and must be completed in July 2017. Perppu consisting of 10 (ten) articles regulates the authority of the government in this case the Directorate General of Tax to view reports containing financial information of customers for tax purposes from financial services institutions conducting activities in the banking sector, capital markets, insurance, other financial services institutions and other entity categorized as a financial institution in accordance with the standards of exchange of financial information under international agreements in the field of taxation (Sukmana, 2017). 
In relation to AEol there is legislation to be fulfilled by the Indonesian government. First, primary legislation is the enactment of the legislation of Perppu No. 1/2017 enacted on May 8, 2017. Second, secondary legislation is the Regulation of the Minister of Finance No. 70/2017 on 31 May 2017. Broadly speaking the content of PMK No. 70 / PMK.03 / 2017 regulates the procedures for reporting financial information, account identification procedures, requirement of documentation by financial institutions, sanctions for noncompliant financial institutions, confidentiality of financial information received by the Directorate General of Tax (DJP) and criminal penalties for Tax officers who do not comply with the provisions of such confidentiality. PMK No. 70 / PMK.03 / 2017 on Technical Guide on Access to Financial Information for Interest of Taxation also requires the banking sector to report customer data with aggregate balances in accounts of at least Rp200.000.000,00 (two hundred million rupiah). The requirement of reporting for the bank related to the customer with a balance of at least Rp200.000.000,00 is reserved for a personally owned financial account, whereas for an entity, entity or company there is no minimum balance limit. This makes the business actors especially Small and Medium Enterprises (SMEs) to be restless, because with account balance of Rp200.000.000,00 has become the target of the Directorate General of tax and impressed the Government wants to pursue the tax of SMEs that should be protected and even given incentives for can survive and develop.

Responding to the public's reaction, the Government again issued the Regulation of the Minister of Finance No. 73 / PMK.03 / 2017 on amendments to the previous regulation, PMK 70 / PMK.03 / 2017 on June 15, 2017, to support the implementation of access to financial information. The Rule stated the amount of balance or account to be reported by the Financial Services Institution (LJK) is at least Rp1,000,000,000.00 (one billion rupiah) or with the equivalent of foreign currency. In the preceding rule, the balance limit must be reported by LJK at least Rp200.000.000,00. The issuance of PMK No. 73 / PMK.03 / 2017, has considered many aspects to make this rule acceptable in the community. This legal provision is necessary because Indonesia will faces the era of financial information disclosure for the purposes of international taxation cooperation (AEol) which is ready to be followed by 140 countries in the world. According to the OECD (Organization for Economic Coorporation and Development) states that in the Common Reporting Standards (CRS) account, all accounts owned by individuals and companies must be reported regardless of their balance value, in the implementation of automatic data exchange for tax purposes. Especially for accounts owned by the company opened before July 1, 2017, must be reported only accounts worth more than US $\$ 250,000$ (approximately Rp3,300,000,000.00) by June 30,2017 . For individuals there is no minimum limit on the value of accounts to be reported. This regulation Announcement is undoubtedly bad information for financial services firms that have been relying on the trust of their customers to keep everything confidential with information about depositors and customer deposits (Quddus, 2017).

Testing of Indonesia capital market reaction to Regulation of the Minister of Finance No. 73 / PMK.03 / 2017 Year 2017 on Amendment to Regulation of the Minister of Finance No. 70 / PMK.03 / 2017 About Technical Guide Regarding Access to Financial Information for Interests of Taxation is an event study. Jones (2012) mentions the event study is an empirical study of the market efficiency of a half-strong form which means that stock returns are examined to determine the impact of an event on stock prices. Testing information content is intended to see the reaction of an announcement. The market reaction is indicated by the price change of the securities. This reaction can be measured by using return as the value of price change or by using Abnormal Return. By using Abnormal Return can be said an announcement that has information content will give abnomal return on the market and vice versa.

Various studies have been conducted related to the event study. Ghani \& Chaudary (2016) tested the monetary policy announcement event on the stock market in Pakistan. The sample used is 14 banks listed in KSE index (Karachi Stock Exchange) 100. To calculate the expectation return, this study used market model. The results of this study show a significant impact of all monetary policy announcements on bank stock returns. While Hall \& Kenjegaliev (2016) tested the event of changes in oil prices on shares of oil companies of 
China and Russia. The result of this study is a big abnormal return generated from shares of oil company, this means the change of oil price responded positively by market. Also the oil company is considered as a strategic company in China and Russia, so vulnerable to political influence.

The issues in this study are whether the Indonesian capital market especially financial services sector companies will react to the Announcement of Regulation of the Minister of Finance No. 73 / PMK.03 / 2017 Year 2017 on Amendment to Regulation of the Minister of Finance No. 70 / PMK.03 / 2017 About Technical Guidelines Regarding Access to Financial Information for Interests of Taxation.

\section{THEORETICAL REVIEW}

Efficient market hypothesis was first proposed and popularized by Fama (1970). Fama (1970) explains that an efficient market is a market where securities prices can "fully reflect" the information available. The definition is emphasized on two aspects of "fully reflect" and "information available". Fully reflect shows that the price of securities strongly reflects the information. The market will be efficient if by using information available to investors, investors can accurately expect the price of the securities in question. Fama (1970) divides the efficient market hypothesis into three forms, namely weak form, semi-strong form, and strong form. On the weak form, the price of the securities already reflects all existing historical information. In semi-strong form, the price of the securities already reflects all public information available. And on the strong-form, the price of the securities already reflects all the information including insider information.

Return is the result of investment. Return can be either the realized Return that has occurred or the Return of expectation that has not happened but is expected to happen in the future. Hartono (2017) defines Return realization as a Return that occurs which can be calculated based on historical data. While Return of expectation is Return expected to be obtained by investor in the future. In contrast to Return realization, Return of expectation has not happened yet.

The event study analyzes the Abnormal Return of securities that may occur around the announcement of an event. Abnormal Return or Excess Return is an excess of normal Return. Normal Return is Return of expectation (Return expected by investor). Thus Abnormal Return is the difference between actual Return that occurred with Return expectations (Hartono 2017).

Table 1 - Previous Research

\begin{tabular}{|c|l|l|l|l|}
\hline No & Author name, year & \multicolumn{1}{|c|}{ Event } & Research Variable & \multicolumn{1}{|c|}{ Conclusion } \\
\hline 1 & Odongo (2013) & $\begin{array}{l}\text { Changes in Capital } \\
\text { Adequacy Regulation }\end{array}$ & $\begin{array}{l}\text { Abnormal Return, } \\
\text { Security Return } \\
\text { Valiability (SRV) }\end{array}$ & $\begin{array}{l}\text { the market reacts negatively to the capital adequacy } \\
\text { announcements as the market returns were } \\
\text { negative in values though the magnitude of the } \\
\text { abnormality was not high. }\end{array}$ \\
\hline 2 & $\begin{array}{l}\text { Rahman, dkk. } \\
(2014)\end{array}$ & $\begin{array}{l}\text { Policy Rate Changes on } \\
\text { Bank Stock Returns in } \\
\text { Pakistan }\end{array}$ & Abnormal Return & $\begin{array}{l}\text { The study finds 31 out of all 35 events have } \\
\text { significant impact on banks stock returns and } \\
\text { returns were normal at 4th day of MP } \\
\text { announcement }\end{array}$ \\
\hline 3 & $\begin{array}{l}\text { Hall dan } \\
\text { Kenjegaliev (2016) }\end{array}$ & $\begin{array}{l}\text { oil price changes on the } \\
\text { price of Russian and } \\
\text { Chinese oil shares }\end{array}$ & $\begin{array}{l}\text { Abnormal Return } \\
\text { tests suggest that the fluctuations in oil prices have } \\
\text { an effect on the stock prices. }\end{array}$ \\
\hline 5 & $\begin{array}{l}\text { Ghani dan } \\
\text { Chaudary (2016) }\end{array}$ & $\begin{array}{l}\text { Evidence from Banking } \\
\text { Sector of Pakistan }\end{array}$ & $\begin{array}{l}\text { Stock Return } \\
\text { The results show significant impact of all monetary } \\
\text { policy announcements on banks stock returns. }\end{array}$ \\
\hline (2017) & $\begin{array}{l}\text { Announcement of Tax } \\
\text { Amnesty Policy On July }\end{array}$ & $\begin{array}{l}\text { Abnormal Return, } \\
\text { Trading Volume } \\
\text { Activity (TVA) }\end{array}$ & $\begin{array}{l}\text { There is an abnormal return difference before and } \\
\text { after the Tax Amnesty Act. }\end{array}$ \\
\hline
\end{tabular}

Table 1 shows some previous research results that have been done by previous researchers. Previous research shows different results. Various studies have been conducted in the format of research event study both from indonesia and from abroad. 
Based on background, literature review and previous research related to the study of events with abnormal return as research variables that have been proposed, it can be described into a frame of thought as follows:

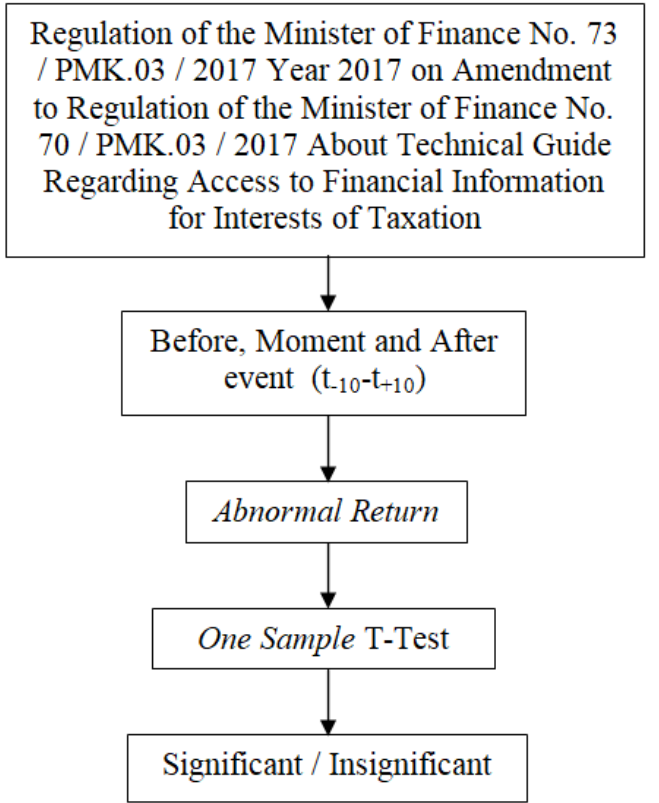

Figure 1 - Research Framework

Based on the conceptual framework that has been proposed, the research hypothesis is proposed as follows: Capital market reacts to the events of the announcement of Regulation of the Minister of Finance No. 73 / PMK.03 / 2017 Year 2017 on Amendment to Regulation of the Minister of Finance No. 70 / PMK.03 / 2017 About Technical Guidelines Regarding Access to Financial Information for the Interest of Taxation shown by the existence of abnormal return or abnormal return is not equal to zero.

\section{METHODS OF RESEARCH}

This research is designed in the form of explanatory or descriptive research design that explains about the subject of market reaction in Indonesia Stock Exchange especially financial services sector to the announcement of Regulation of the Minister of Finance No. 73 / PMK.03 / 2017 Year 2017 About Technical Guide Regarding Access to Financial Information for Interest of Taxation. To obtain a complete picture of the subject, this study starts from the data collected including daily stock price, $\mathrm{JCl}$ daily and the date of announcement of Regulation of the Minister of Finance No. 73 / PMK.03 / 2017 Year 2017 on Amendment to Regulation of the Minister of Finance No. 70 / PMK .03 / 2017 Concerning Technical Guidelines on Access to Financial Information for Interests of Tax. Date of Regulation of the Minister of Finance No. 73 / PMK.03 / 2017 Year 2017 Concerning Amendment to Regulation of the Minister of Finance No. 70 / PMK.03 / 2017 Regarding Technical Guide Regarding Access to Financial Information for Interests of Taxation in this study is indicated by $t=0$ in the period of the event or event window period. The period of observation is ten days prior to the day of the announcement, on the day of the announcement, and ten days after the day of Regulation of the Minister of Finance No. 73 / PMK.03 / 2017 Year 2017 on Amendment to Regulation of the Minister of Finance No. 70 / PMK.03 / 2017 About Technical Guidelines Regarding Access to Financial Information for Interests of Taxation. Location of this research is a financial services sector companies listed on the Indonesia Stock Exchange (IDX) in 2017. Indonesia Stock Exchange provides information on financial statements by accessing the official website that is www.idx.co.id and also through yahoo finance website (finance.yahoo.com). The population used in this 
study is the financial services sector companies listed on the Indonesia Stock Exchange period 2017, amounted to 86 companies. Sampling technique is purposive sampling that is election by using specific criteria. Obtained sample of 58 companies that can be seen in table 2.

Table 2 - Selection of Research Sample

\begin{tabular}{|c|c|}
\hline Description & Total \\
\hline Population & 86 \\
\hline data not available & 10 \\
\hline Inactive trading & 8 \\
\hline has extreme data & 10 \\
\hline number of samples & 58 \\
\hline
\end{tabular}

Source : Processed by author in 2018.

The type of data collected is in the form of quantitative data which includes daily stock price, $\mathrm{JCl}$ Daily from 58 samples of financial services sector companies listed on the $\mathrm{BEI}$ in 2017.

Dependent variable to be analyzed in this study is Abnormal Return. And the independent variable is the Event of Announcement of Regulation of the Minister of Finance No. 73 / PMK.03 / 2017 Year 2017 About Technical Guidelines Regarding Access to Financial Information for Interests of Taxation. The collected data is then processed so that it can be compared between t-count with t-table to determine whether or not there a significant abnormal return in the event. The stages of the data analysis methods are listed as below:

- Calculating Return Realization, Return Realization is calculated by reducing the price on one day $(\mathrm{Pt})$ with the previous day's price $(\mathrm{Pt}-1)$ then dividing the result with the previous price (Pt-1).

- Calculating Return of Expectation, The calculation of expected return in this study using market adjusted model. Market Adjusted Model assumes that the best estimator to estimate the return of a securities is the market index return at that time (Hartono, 2017).

- Calculating Abnormal Return, Abnormal Return is the difference between the actual return that occurs with the expectation return.

- Calculating cumulative abnormal Returns, cummulative abnormal return (CAR) is the sum of abnormal returns the previous day in the event period for each of the securities.

Statistical test of abnormal return has the purpose to see the significance of abnormal returns that exist in the event period. The significance in question is that the abnormal return is statistically significant not equal to zero (positive for good news and negative for bad news) (Hartono, 2017). The technical of the test in this study is to compare t-count with t-table.

\section{RESULTS AND DISCUSSION}

In accordance with the framework of thought and hypotheses of research that have been determined, the analysis technique used in this study is statistical analysis of one sample t-test. The results of the Descriptive Statistics of cummulative abnormal return (CAR) test in Table 3 show the average value, maximum value, minimum value, standard deviation of the research object on the event of announcement Regulation of the Minister of Finance No. 73 / PMK.03 / 2017 Year 2017 About Technical Guidelines Regarding Access Financial Information for Interests of Taxation.

Based on table 3, CAR in the period of announcement of Regulation of the Minister of Finance No. 73 / PMK.03 / 2017 Year 2017 About Technical Guide Regarding Access to Financial Information for Interests of Tax. Minimum CAR value in the period of announcement of Regulation of the Minister of Finance No. 73 / PMK.03 / 2017 Year 2017 About Technical Guide Regarding Access to Financial Information for Interest of Tax at $41.18 \%$ contained in the company Insurance Jaya Tania Tbk. (ASJT) while the maximum 
CAR value is around the Announcement of Regulation of the Minister of Finance No. 73 / PMK.03 / 2017 Year 2017 on Technical Guide on Access to Financial Information for Tax Interest in $18.77 \%$ of Bank Pan Indonesia Tbk (PNBN). Mean value of CAR around the announcement of Regulation of the Minister of Finance No. 73 / PMK.03 / 2017 Year 2017 About Technical Guide on Accessing Financial Information for Tax Interest at $-3.47 \%$ with standard deviation of $10.81 \%$.

Table 3 - Descriptive statistics

\begin{tabular}{|c|c|c|c|c|c|}
\hline- & $\mathrm{N}$ & Minimum & Maximum & Mean & Std. Deviation \\
\hline car & 58 &,- 4118 &, 1877 &,- 034719 &, 1081927 \\
\hline Valid N (listwise) & 58 & & & & \\
\hline
\end{tabular}

Source : Data analysis by using SPSS (2018).

Testing for normaliity was performed using the Kolmogorov Smirnov Test statistic test method in testing the mean difference. If the calculation of normality test data shows the value of sig. 2 tailed> 0.05 then the data is normally distributed and then the data can be tested by Test One Sample t-test. The results obtained as shown in Table 4 above show that asymptotic significant values in Cumulative Abnormal Return of 0.098 in the period of announcement of Regulation of the Minister of Finance No. 73 / PMK.03 / 2017 Year 2017 About Technical Guide Regarding Access to Financial Information for Tax Interest, the sig value of 0.098 is greater than 0.05 it can be concluded that the Cumulative Abnormal Return data before the announcement event Regulation of the Minister of Finance No. 73 / PMK.03 / 2017 Year 2017 About Technical Guidelines Regarding Access to Financial Information for Tax Interest Normally distributed, so to analyze the significance of abnormal return in the event period may use a one sample t-test.

Table 4-Normality Test

\begin{tabular}{|c|c|c|}
\hline \multicolumn{2}{|c|}{-} & CAR \\
\hline \multicolumn{2}{|c|}{$\mathrm{N}$} & 58 \\
\hline \multirow[t]{2}{*}{ Normal Parameters $^{a, b}$} & Mean &,- 034719 \\
\hline & Std. Deviation & ,1081927 \\
\hline \multirow[t]{3}{*}{ Most Extreme Differences } & Absolute & ,107 \\
\hline & Positive &, 072 \\
\hline & Negative &,- 107 \\
\hline \multicolumn{2}{|c|}{ Test Statistic } & 107 \\
\hline \multicolumn{2}{|c|}{ Asymp. Sig. (2-tailed) } &, $098^{\mathrm{C}}$ \\
\hline
\end{tabular}

Source : Data analysis by using SPSS (2018).

Testing of significance to CAR is done by comparing t-count with t-table value of 2,00247 (sig 5\%) during the period of the event with Ho testing criteria accepted and $\mathrm{H} 1$ rejected if $-\mathrm{t}$ table $<\mathrm{t}$ arithmetic $<\mathrm{t}$ table, otherwise $\mathrm{Ho}$ is rejected and $\mathrm{H} 1$ received if- $\mathrm{t}$ arithmetic <-t table or $t$ arithmetic $>t$ table with probability $P$ value $<0.05$. Hypothesis in this research are:

Table 5 - One Sample t-Test

\begin{tabular}{|c|c|c|c|c|c|}
\hline \multicolumn{6}{|c|}{ Test Value $=0$} \\
\hline \multirow{2}{*}{$\mathrm{t}$} & \multirow{2}{*}{$\mathrm{df}$} & \multirow{2}{*}{ Sig. (2-tailed) } & \multirow{2}{*}{ Mean Difference } & \multicolumn{2}{|c|}{$95 \%$ Confidence Interval of the Difference } \\
\hline & & & & Lower & Upper \\
\hline$-2,444$ & 57 & ,018 &,- 0347190 &,- 063167 &,- 006271 \\
\hline
\end{tabular}

Source : Data analysis by using SPSS (2018).

Abnormal return test results with one sample t-test shows the value of t-count and significance of abnormal return in the event period. From the test results, Cumulative Abnormal Return in the event period is statistically significant seen from the value of $t$ arithmetic compared with t-table is $-2.444<-2.00247$ with probability $0.018<0.05$ then $\mathrm{Ho}$ is 
rejected and $\mathrm{H} 1$ accepted. A negative-valued t-test means that investors' reactions result in investors getting negative abnormal returns or capital losses.

Regulation of the Minister of Finance No. 73 / PMK.03 / 2017 Year 2017 About Technical Guide Regarding Access to Financial Information for Tax Interest This is a followup of Tax amnesty program (Tax Amnesty) which used theme of information access disclosure for taxation activities and is one of the requirements for Indonesia can join AEol (Automatic Exchange of Information). This Regulation of the Minister of Finance (PMK) also implies the discretion of the Directorate General of Taxes to know the accounts of all Indonesian Citizens (WNI) in indonesia and outside the country, as well as foreigners (WNA) in Indonesia. However, financial service companies should have anticipated when the tax amnesty program is implemented so that the expected impact on the financial services company is not significant negative. But in reality the response given by investors to this event is negative and significant. This can be because there are still taxpayers who do not follow the tax forgiveness program or taxpayers who follow the tax forgiveness program does not disclose all the assets they have (Doly, 2018) can cause this PMK responded negatively. The Government responds to this by giving the Taxpayer another opportunity to report his property correctly through the PAS Final program (Disclosure of Voluntary Assets with Final rate- after Tax Amnesty program) because there is no more gap for taxpayers to hide their wealth (Deny, 2017).

In general the findings in this study indicate Announcement of Regulation of the Minister of Finance No. 73 / PMK.03 / 2017 Year 2017 on Amendment to Regulation of the Minister of Finance No. 70 / PMK.03 / 2017 About Technical Guide Regarding Access to Financial Information for Interests Taxation affects investor expectations to inculcate funds in the financial services sector. Investors are more cautious in investing because the announcement of the PMK gives a negative sentiment on the shares of financial services companies, but the performance of financial services companies are still considered good enough by the observers of the capital market encourages investors not to overreact on the occurrence of this PMK announcement and predicted this reaction only is temporary because of the Final PAS program is expected to overcome and be a solution of the fear of the Taxpayer who has not reported his assets. On the basis of such matter if at any time there is a similar regulation announcement is expected investors do not sell its shares, because the reaction of this rule is only temporary.

\section{CONCLUSION}

Based on the results of the discussion and analysis of the acquisition of Abnormal Return of shares sampled around the date of announcement can be summarized as follows:

- Announcement of Regulation of the Minister of Finance No. 73 / PMK.03 / 2017 Year 2017 on Amendment to the Regulation of the Minister of Finance No. 70 / PMK.03 / 2017 Concerning Technical Guide on Access to Financial Information for Tax Interest results negative market reaction.

- Announcement of Regulation of the Minister of Finance No. 73 / PMK.03 / 2017 Year 2017 Concerning Amendment to Regulation of the Minister of Finance No. 70 / PMK.03 / 2017 Regarding Technical Guide Regarding Access to Financial Information for interest of Taxation causes a market reaction so the announcement contains information (information content) shown by the existence of a significant Abnormal Return around the event period.

From some conclusions obtained should be submitted suggestions as follows:

- investors need to anticipate and analyze any information that may affect investment decision making. so investors are advised to attempt to obtain as much information and review the information, especially information that allegedly can affect the capital market so that it can take the right decision in the investment.

- Because the cumulative Abnormal Return obtained is negative and it means that the market response negatively to this announcement. So government should respond by suggest to the public, especially taxpayers who do not follow the tax amnesty 
program or taxpayers who have followed the tax amnesty program but did not disclose all assets which he has, to participate in the PAS Final program.

- Develop similar research in other fields, given the reaction of capital market actors who react not only because of political and economic events, but also other events that affect people's lives.

\section{REFERENCES}

1. Beaver, W. H. (1968). The Information Content of Annual Earning Releases: A Trading Volume Approach. Supplement to journal of Accounting Research, 67-92.

2. Brown, S. J., \& Warner, J. B. (1985). Using Daily Stock Returns. Journal of Financial Economics, 14(1), 3-31. https://doi.org/10.1016/0304-405X(85)90042-X.

3. Campbell, John Y., (1997). The Econometrics of Financial Markets. Second printing, with corrections. New Jersey : Princeton University Press.p.149-181.

4. Fama, E. F. (1970). Efficient Capital Markets: A Review Of Theory \& Empirical Work. The Journal of Finance, 25(2), 383-417. Retrieved from http://www.jstor.org/

5. Ghani, M., \& Chaudhary, G. M. (2016). Stock Market Response to Policy Announcement: Evidence from Banking Sector of Pakistan, 6(1). Retrieved from www.iiste.org.

6. Hall, S. G., \& Kenjegaliev, A. (2017). The effect of oil price changes on the price of Russian and Chinese oil shares. Empirical Economics, 53(4), 1639-1656.

7. Hartono, J. (2017). Teori Portofolio dan Analisi Investasi. Edisi kesebelas. Yogyakarta.

8. Jones, C. P. (2012). Investment Analysis and Management. twelfth edition. New York, NY: John Wiley \& Sons, Icn.

9. Kencana, K. C. (2017). Rahasia Perbankan dan Pemeriksaan Pajak (artikel online). Diakses 24 September 2017. Available from URL : http: /www.pajak.go.id/

10. Odongo, F. O. (2013). Stock Price Reaction to Changes In Capital Adequacy Regulation in the Kenyan Banking Sector University of Nairobi.

11. Peraturan Bank Indonesia nomor: 2/19/PBI/2000.

12. Peraturan Menteri Keuangan Nomor 70/PMK.03/2017 tentang Petunjuk Teknis (Juknis) mengenai Akses Informasi Keuangan untuk Kepentingan Perpajakan dari Peraturan Pemerintah Pengganti Undang-Undang (Perppu) Nomor 1 Tahun 2017 tentang Akses Informasi Keuangan untuk Kepentingan Perpajakan.

13. Peraturan Menteri Keuangan Nomor 73/PMK.03/2017 Tahun 2017 Tentang Perubahan Atas Peraturan Menteri Keuangan Nomor 70/PMK.03/2017 Tentang Petunjuk Teknis Mengenai Akses Informasi Keuangan untuk Kepentingan Perpajakan

14. Peraturan Pemerintah Republik Indonesia Nomor 36 tahun 2017 tentang pengenaan Pajak Penghasilan Tertentu berupa Harta Bersih yang Diperlakukan atau Dianggap sebagai Penghasilan.

15. Quddus, G. G. (2017). Terbit, PMK baru batas minimum saldo Rp 1 miliar. 2017. Kontan.co.id. Access on: http://nasional.kontan.co.id/news/terbit-pmk-baru-batasminimum-saldo-rp-1 miliar.

16. Rahman, habib ur, Mohsin, H. M., \& Rivers, P. A. (2014). The Effect of Policy Rate Changes on Bank Stock Returns in Pakistan. Journal of Finance and Economics, 2(4), 116. https://doi.org/10.12735/jfe.v2i4p01.

17. Sugiyono. (2016). Metode Penelitian Bisnis. Cetakan Kesepuluh. Bandung. pp. 215-216.

18. Sukmana, Y. (2017). Di Hadapan DPR, Sri Mulyani Bicara Tumpulnya Ditjen Pajak. 2017. Kompas.com. access on: http://ekonomi.kompas.com/

19. Undang-Undang N28 tahun 2007 tentang Ketentuan Umum Dan Tata Cara Perpajakan.

20. Wijaya, K. (2016). Masalah single presence policy (SPP) bank pemerintah. diakses tanggal 30 Nopember 2016. Access on : http://www.bisnis.com/. 